\title{
IDENTIFYING PROBLEMS IN STUDENTS’ FINAL PROJECTS BASED ON SCIENTIFIC WRITING GUIDELINES
}

\author{
Endang Ernawati
}

English Department, Faculty of Language and Culture, Bina Nusantara University, Jln. Kemanggisan Ilir III No. 45, Kemanggisan/Palmerah, Jakarta Barat 11480, ernaw@binus.edu

\begin{abstract}
Article analyzed student's difficulties and abilities in writing their final projects, which were undergraduate theses and undergraduate paper conducted by some students at the English Department, Bina Nusantara University. This was a preliminary study to support an appropriate student guideline in writing their final project. The study was conducted by applying qualitative methods that was by analyzing the four theses and one paper in terms of their format: titles, introduction, theoretical background, analysis, conclusion, bibliography, and paper rubric to analyze the contents. It can be concluded that generally, students, guided by their mentor/lecturer, understand the final paper guidelines and they are able to apply it in their thesis and paper. But, there are still lack of clarity and relevancy in expressing their ideas properly, and their ability in writing in both English and Bahasa Indonesia must be improved. These problems can be overcome by socializing the writing guidelines to both students and lecturers, providing them with critical thinking skills, cooperation with library that will guide them in information literacy skills, and language center that will improve their writing skills.
\end{abstract}

Keywords: final project, scientific writing, writing guidelines, undergraduate theses, paper

\begin{abstract}
ABSTRAK
Artikel menganalisis kesulitan dan kemampuan mahasiswa untuk menulis tugas akhir mereka berdasarkan Panduan penulisan Tugas Akhir yang telah diterbitkan Jurusan Sastra Inggris, Fakultas Bahasa dan Budaya, Universitas Bina Nusantara. Studi ini merupakan langkah awal untuk melakukan kajian penulisan ilmiah yang lebih spesifik dan penulisan pedoman penulisan karya ilmiah yang lebih tepat buat mahasiswa di Binus. Studi dilakukan dengan metode kualitatif, yaitu menganalisis 4 thesis dan 1 paper di bawah bimbingan penulis. Analisis dilakukan dengan menilai format penulisan, yaitu judul, pendahuluan, landasan teori, analisis, simpulan, penulisan daftar pustaka berdasarkan APA, dan analysis kandungan tulisan berdasarkan rubrik. Disimpulkan, mahasiswa dengan arahan dosen pembimbing mampu menafsirkan panduan penulisan ke dalam karya tugas akhir mereka dengan baik, tetapi masih terdapat kekurangan terkait dengan "clarity" dan "relevancy" di dalam mengekspresikan isi penelitian, dan kelemahan dalam penulisan dalam bahasa Inggris dan bahasa Indonesia. Kelemahan ini dapat diatasi dengan sosialisasi pedoman penulisan ilmiah kepada mahasiswa dan dosen pembimbing, bekerja sama dengan perpustakaan yang akan membimbing mereka menguasai ketrampilan berliterasi informasi, dan Pusat Bahasa yang akan membina kemampuan berbahasa mereka.
\end{abstract}

Kata kunci: tugas akhir, penulisan ilmiah, pedoman penulisan, skripsi, paper 


\section{INTRODUCTION}

Subjects related to students' ability in scientific writing have been taught from the early semesters; namely writing, grammar, research methods, and scientific writing. Those subjects are taught to foster students' cognitive and affective aspects of learning. The main purpose is for the students to be able to do research as well as write their report in the form of undergraduate theses and paper properly.

To support class learning process, library as the heart of the university, has Information Literacy (IL) programs in which the library users are educated to be independent in finding information. Practice in library operation is done by proper placement of books and non-books collections, education on how to access and use them properly, and then utilize all those collections legally and ethically in the form of scientific writing. Educating library users to be information literate is by motivating them to recognize information they need, ability to find the appropriate information, and use them properly to create a new knowledge/information that will be documented and publish as library collections.

In writing Undergraduate theses, students were guided by lecturers, in which they are guided to apply skills and theories of Scientific Writing into a real research and undergraduate theses as a requirement to achieve S1 degree. Lecturer guidance is conducted in one semester or at least ten times consultation until the undergraduate theses is finished.

So, it can be said that students are already prepared properly before they conduct research and write undergraduate theses and paper. The provisions of writing skills, research method, and scientific writing are already given with the purpose of producing a good quality thesis, but in reality, qualified undergraduate theses have not really been achieved.

\section{METHODS}

The study used qualitative method. Article explored four undergraduate theses and one Diploma paper in their application of scientific writing rules. To what extent the students were able to apply scientific writing rules in their scientific writing in terms of formats and paper rubric. Study was done by qualitative method in which four undergraduate theses and one Diploma (D3) paper with the following titles listed in Table 1 were explored.

Table 1 List of Theses and Paper Explored in this Research

\begin{tabular}{|c|c|c|c|c|}
\hline No & Author & Year & Title & Type \\
\hline 1 & Yuliastuti. & 2005 & $\begin{array}{l}\text { Analysis of the Conscious and Unconscious Mind of } \\
\text { Sheila's Behavior in One Child by Torey Hayden }\end{array}$ & Undergraduate theses \\
\hline 2 & Wendy Wijaya & 2010 & $\begin{array}{l}\text { The Analysis of Racism through Characters Derek } \\
\text { Vinyard and Daniel Vinyard in American History X } \\
\text { Movie }\end{array}$ & Undergraduate theses \\
\hline 3 & $\begin{array}{l}\text { Maria Hernanda Ika } \\
\text { Kristiani }\end{array}$ & 2009 & $\begin{array}{l}\text { An Analysis of Woman's Struggle in Upholding the } \\
\text { Family Honour in a Walt Disney Movie Mulan }\end{array}$ & Undergraduate theses \\
\hline 4 & Siska Yuliana & 2009 & $\begin{array}{l}\text { Semiotic Analysis on Sign Across Non-Verbal } \\
\text { Communication in Ferd'nand Wordless Comic Strip }\end{array}$ & Undergraduate theses \\
\hline 5 & Imelda Liaury & 2004 & $\begin{array}{l}\text { An Analysis of Sheila's Character in One Child by } \\
\text { Torey Hayden }\end{array}$ & Paper of D3 Program \\
\hline
\end{tabular}




\section{Introduction Analysis}

This study was based on Scientific Writing Regulation published by the English Department, Faculty of Language and Culture, Bina Nusantara University. Thesis or students' final project have been analysed based on their structure, these elements were title; abstract; keywords; introduction consisting of background, problems, scope and limitation, goals, and research methods; theoretical background; analysis; conclusion; summary; references; and rubric analysis.

Scientific Writing regulation for undergraduate theses and paper from the English Department, Binus University is summarised as follows (Binus University English Department, 2010).

An undergraduate thesis (skripsi) is divided into 5 chapters.

Chapter 1: Introduction, consisting of:

\section{Background of Study}

Described general problems, why did the writer interested to the topic, the advantage of researching the topic.

\section{Problem Formulation}

Problems were issued by the writer to find its solution/answers. Problem identity can be in either in affirmative or question sentence. The answer of the problem must be conducted by research.

\section{Scope and Limitation}

This sub title clarified scope and the limitation which is the smaller than the scope that will be analyzed, for example the scope is the novel, drama, the subject or research, while the limitation was the main character, methods of teaching subject, object of the research, analyzed data, etc. The purpose of defining this scope and limitation is to create the focus of the research.

\section{Goal(s) and Functions(s)}

Goals were achievements that will be presented in the end of research. Goals can be the answer or solution of the problems. Functions was the condition if the goals were already achieved, taken from the readers' point of view. It is optional in the research.

\section{Research Methods}

This is a slight clarification of methods that will be explored in Chapter 3: Analysis. The writer can mention the way the research will be conducted; those are qualitative or quantitative research. In general the methods mention respondent, informants, research instruments: questionnaires, interview guidance, time, and place. Qualitative research can be in the type of library research, and the writer has to mention theories that will be applied in analysis.

\section{Chapter 2: Theoretical Background}

This chapter presents some theories from many experts related to the topic of research. The writer quotes properly based on APA style to avoid plagiarism. Review of some past researches was done by mentioning problems, goals, and methods, and results that have been done to previous research. By presenting this review, the writer will know the position of this research among those that have been done, as well as showing the value of the research.

\section{Chapter 3: Research Analysis}

This chapter is the essence of the research in which the writer will analyse how to collect, analyse, and evaluate data based on the goals of research and of course the research problems. If the writer does a library research, this chapter will analyse the main character based on the chosen theories. 


\title{
Chapter 4: Conclusion and Suggestions
}

Conclusions describe the essence of research that is in line with problem formulation and goals of the research. The statement must be clear and concise. Suggestions are optional. It can be a chance of the future research that can be done by the next students.

\section{Chapter 5: Summary}

Summary clarifies the research in Bahasa Indonesia that describes the research in order the nonIndonesia readers understand the background, methods, and conclusion of the research.

(Binus University English Department, 2010)

\begin{abstract}
After writing undergraduate theses, the writer should complete it with abstract which is a "miniature" of the research. Abstract functions as a "short description" in which the readers can grasp the research and decide to continue to read the whole thesis or not. Abstract consists of goals, method, analyse, and conclusion of the research. (APA, 2007).
\end{abstract}

\section{Quotation}

Quotation format was written based on APA style of writing. Quotations consist of direct and indirect quotation. Direct quotation permits the writer writes "statement" as it was written on the literature sources with a limited portion, while indirect quotation was done by paraphrasing the sources to avoid plagiarism. The basic quotation format was name of author, year of publication, and the related page(s).

\section{References}

Writing references is also written based on APA style of writing. It is done for textbooks (author, year of publication, title, (edition), city, publisher); articles (author, (month, year), title of article, title of journal, volume, number, and related page. If the writers use articles from the internet, they have to mention year of upload, time when the writers get the information, and its URL address. Based on APA style, author is written by last name first and followed by its initials. Title of book/article was written by preceding capital letter, followed by title case, except for personal name and place.

For additional analysis, the study used Research paper rubric to evaluate grade the whole undergraduate theses and paper content, as follows.

Table 2 Research Paper Rubric

$\begin{array}{llll} & \text { Expert } & \text { Proficient } & \text { Apprentice }\end{array}$


Table 2 Research Paper Rubric (continued)

\begin{tabular}{|c|c|c|c|c|}
\hline & Expert & Proficient & Apprentice & Novice \\
\hline $\begin{array}{l}\text { Depth of } \\
\text { Discussion }\end{array}$ & $\begin{array}{l}\text { In-depth discussion \& } \\
\text { elaboration in all sections of } \\
\text { the paper. }\end{array}$ & $\begin{array}{l}\text { In-depth discussion \& } \\
\text { elaboration in most } \\
\text { sections of the paper. }\end{array}$ & $\begin{array}{l}\text { The writer has omitted } \\
\text { pertinent content or } \\
\text { content runs-on } \\
\text { excessively. Quotations } \\
\text { from others outweigh the } \\
\text { writer's own ideas } \\
\text { excessively. }\end{array}$ & $\begin{array}{l}\text { Cursory discussion in all } \\
\text { the sections of the paper } \\
\text { or brief discussion in } \\
\text { only a few sections. }\end{array}$ \\
\hline Cohesiveness & $\begin{array}{l}\text { Ties together information from } \\
\text { all sources. Paper flows from } \\
\text { one issue to the next without } \\
\text { the need for headings. } \\
\text { Author's writing demonstrates } \\
\text { an understanding of the } \\
\text { relationship among material } \\
\text { obtained from all sources. }\end{array}$ & $\begin{array}{l}\text { For the most part, ties } \\
\text { together information from } \\
\text { all sources. Paper flows } \\
\text { with only some } \\
\text { disjointedness. Author's } \\
\text { writing demonstrates an } \\
\text { understanding of the } \\
\text { relationship among } \\
\text { material obtained from all } \\
\text { sources. }\end{array}$ & $\begin{array}{l}\text { Sometimes ties together } \\
\text { information from all } \\
\text { sources. Paper does not } \\
\text { flow. Author's writing } \\
\text { does not demonstrate an } \\
\text { understanding of the } \\
\text { relationship among } \\
\text { material obtained from } \\
\text { all sources. }\end{array}$ & $\begin{array}{l}\text { Does not tie together } \\
\text { information. Paper does } \\
\text { not flow and appears to } \\
\text { be created from disparate } \\
\text { issues. Headings are } \\
\text { necessary to link } \\
\text { concepts. }\end{array}$ \\
\hline $\begin{array}{l}\text { Spelling \& } \\
\text { Grammar }\end{array}$ & $\begin{array}{l}\text { No spelling \&/ or grammar } \\
\text { mistakes. }\end{array}$ & $\begin{array}{l}\text { Minimal spelling \&/or } \\
\text { grammar mistakes. }\end{array}$ & $\begin{array}{l}\text { Noticeable spelling \& } \\
\text { grammar mistakes. }\end{array}$ & $\begin{array}{l}\text { Unacceptable number of } \\
\text { spelling and/or grammar } \\
\text { mistakes. }\end{array}$ \\
\hline Sources & $\begin{array}{l}\text { More than } 5 \text { current sources, } \\
\text { of which at least } 3 \text { are peer- } \\
\text { review journal articles or } \\
\text { scholarly books. Sources } \\
\text { include both general } \\
\text { background sources and } \\
\text { specialized sources. Special- } \\
\text { interest sources and popular } \\
\text { literature are acknowledged as } \\
\text { such. All website utilized are } \\
\text { authoritative. }\end{array}$ & $\begin{array}{l}5 \text { current sources, of which } \\
\text { at least } 2 \text { are peer-review } \\
\text { journal articles or scholarly } \\
\text { books. All websites } \\
\text { utilized are authoritative. }\end{array}$ & $\begin{array}{l}\text { Fewer than } 5 \text { current } \\
\text { sources or fewer than } 2 \\
\text { of } 5 \text { are peer-reviewed } \\
\text { journal articles or } \\
\text { scholarly books. All } \\
\text { websites utilized are } \\
\text { credible. }\end{array}$ & $\begin{array}{l}\text { Fewer than } 5 \text { current } \\
\text { sources or fewer than } 2 \\
\text { of } 5 \text { are peer-reviewed } \\
\text { journal articles or } \\
\text { scholarly books. Not all } \\
\text { websites utilized are } \\
\text { credible, and/or sources } \\
\text { are not current. }\end{array}$ \\
\hline Citations & $\begin{array}{l}\text { Cites all data obtained from } \\
\text { other sources. APA citation } \\
\text { style is used in both text and } \\
\text { bibliography. }\end{array}$ & $\begin{array}{l}\text { Cites most data obtained } \\
\text { from other sources. APA } \\
\text { citation style is used in } \\
\text { both text and bibliography. }\end{array}$ & $\begin{array}{l}\text { Cites some data obtained } \\
\text { from other sources. } \\
\text { Citation style is either } \\
\text { inconsistent or incorrect. }\end{array}$ & Does not cite sources. \\
\hline
\end{tabular}

Source: Cornell \& Colorado (2004)

\section{RESULTS AND DISCUSSIONS}

\section{Title Analysis}

Titles that the students chose have met the requirements. Their titles' lengths are varied from 10 words to 14 words and cover analysis of the chosen topics. (see the theses and paper titles in the methods section).

\section{Introduction Analysis}

Referring to the format of four undergraduate theses and one paper, it can be said that all the students have already known and aware of its format. All of these final papers are consisted of: title, abstract, table of content, Introduction, Theoretical Background, Analysis, Conclusion and Suggestion, and Summary. Based on Cooley and Lewkowics (2003:9), there are still many weaknesses made by the authors that need further guidance from their lecturers. The analysis using rhetorical moves is as follows. All the four undergraduate theses and paper have already contained background, problems formulation, scope and limitation, goals, and research methods. But, they are not written in focus, for example in writing background of study, the authors cannot mention clearly why they are interested in the topics that will be developed into their researches. 
Thesis No 1 did not mention the background properly but the author mentioned the main problem as follows, “... But, when there is something going wrong in the family, like divorce or bad things that happens in their family, it will influence their own children's life". This thesis statement will be proved in the research. The fact, the background should mention the writer's interests in conscious and unconscious mind of a child, not the effects of broken parents to their child. Thesis No 2 presented racism topic and its background still explores deeply on racism, for example by showing a definition to conform the meanings, and followed by thesis statement that said,”... People have different perception in understanding racism..." that will be proved in the analysis through a comparison between of Derek and Daniel Vinyard's characters. So, this thesis has a good clarity and relevance in their topic and background presentation.

There is a good correlation between topic and background of study presented in thesis No 3 . The topic title was"... women struggle in upholding the family honours", and the background that said,”...women must struggle hard to prove themselves in society.” In this relationship, upholding the family honours can be closely associated to women struggle to develop their roles in society.

Siska Yuliana (2009) in thesis No 4 mentioned "non-verbal communication" as having (wordless) comic as object media, while in her background of study she started "communication" as the basic concept, followed by verbal and non-verbal communication. In the last part, her thesis statement said that,”... Unfortunately, not all people understand the meaning of comic, ... therefore the readers cannot enjoy and understand the comic.” In her paper, Siska defined Ferd'nand comic strip as a combination between picture and body language. This thesis presented a good correlation, which is clarity and relevancy between the chosen topic and its background.

Related to the paper No 5 title, irrelevance between title and background is also found where the title was "Analysis of Sheila's Character ..." and the background said, "Whenever they (parents) are separated, children are the first suffering objects for its impact". So, the author interests to Sheila's unusual character and parent's behaviour is totally different.

Evaluating from the clarity and relevancy point of view, it can be concluded that from the 4 undergraduate theses and 1 paper, there are 3 theses and one paper that meet the requirement. The indicator is the availability of a strong indicator tone in the first and second paragraph of those thesis and paper. As of, the following sentences that said:

1. "This thesis will analyse a novel entitled ,...."

2. "In order to prove that racism and its impact still exist, the writer chooses ...movie which offers more rationale storyline about racism"

3. "This research analyses wordless comic using Ferd'nand comic strips.” ...

4. "The focus of discussion in this thesis is on the main character ..."

5. "This paper will analyse Sheila, ... that had been abandoned by her mother and lived with her drunken father."

Those sentences indicated that the authors already aware of their purpose in doing the library researches by mentioning media (novel, comic, and movie) and the related topics, such as the main character of the media.

\section{Review of Related Literatures}

One of the relevance factors in research indicates its review on the previous researches having the same topic s. By doing literature review, the researchers prove that they are able to analyse others' work so that they know position or "state of the art" of their present researches and they are able to communicate or know the link of the former researches. Literature review also proves that the researchers have a good critical thinking in which they want to create a new aspect of the same topic 
of research, for example by applying different method, problem formulation, goals, object of research, and analysis. Literature review presented in the final project is as follows.

Yuliastuti (2005) presented literature review in "Summary of the Related Paper” in Chapter 2 by clarifying papers that she have explored. But, she did not mention what the difference and values that she would do in her next research. She also mentioned 15 textbook and no articles in her Bibliography at the end of her thesis.

Wendy Wijaya (2010) presented literature review from his bibliography that is consisted of 23 textbooks, 1 thesis, 2 journal articles, and 1 reference book. In his first chapter he stated,” The thesis with racism topic has already researched by many people, for example .... by Yuliani, a Binusian 2008. The problem presented ....The goals ... .The research analysis ...., and conclusion."

Wendy also mentioned “another research related in racism issue by Jessica Ringrose (2003).”. He mentioned Jessica's quantitative research, He also analyzed an article wrote by John Bird in 2007 with the topic "Psychoanalysis and racism". He explored the research's problem, goals, applied library research, theories, analysis, and conclusion clearly. Finally, Wendy related those previous researches with his by saying that," Based on the related literature research in racism issue above, it can be considered that the writer's research is useful to conduct and will be presented in a thesis entitled ....”

There was no literature review in the thesis No 3. Maria Hernanda Ika Kristiani (2009) did not present literature review. From 9 references, she only presented one journal article (by Ming Tsui and it was not deeply analysed). She quoted the content of article as a theory in Chapter 2 that she would apply in her analysis. The article presented the division of Chinese family.

Siska Yuliana (2009) in thesis No 4 only mentioned 19 textbooks and 3 reference books in her References, with no journal articles. That was why she could not present the literature review, instead of some definitions and theories in Chapter 2, Theoretical Background. Imelda Liaury (2004) did not present literature review in chapter 1 , and she only had 11 textbooks and no journal articles in her bibliography.

From literature review analysis, it can be concluded that only one thesis that presents literature review with the purpose of saying that his research is valuable enough to be conducted. It means that he can learn from others' research some points related to his topic. This literature review was closely related with his bibliography consisting of 1 related thesis and 2 articles as comparison and input. It was the current thesis (2010) when the writer has been guided, so it can be said that the more current research, the more students are aware of the utilization of primary sources that is article and thesis. Therefore, the skill of information retrieval, such as finding and using e-scientific journal, retrieving information from internet, by applying simple and advance search must be prioritized. To support this needs, reference librarians plays important role in developing information literacy, that is how to recognize the needed information, how to find them, and use them legally to create new knowledge.

On the other hand, literature review also indicates that the student researchers need some guidance related to the theories that will be used in research. Usually, students choose theories only based on previous research and not from exploring other researches or the impacts on theories for the result and conclusion. This indicates that the students were not capable of integrating or comparing each reference they obtained. They have not explored the correlation of one researcher and the other in defining theories and methods they have chosen, do they have same basic thinking in doing research with the same topic? In reality, the student researchers just made a bibliographic list having subject or keyword related to their thesis topic. In this case, students need guidance in how to evaluate others' primary research to choose their real research, and critical thinking skills that will develop students' skill in evaluating others' researches. 
The awareness of doing literature review based on primary research is in line with the university policy to develop research and publication that becomes the main priority at present. The utilization of article and previous research as primary sources should be socialized to users; namely lecturers, students, and researchers in Binus University. Ministry of National Education support in the form of e-journal subscription and some research grants are also utilized by students.

\section{Problems, Scope and Limitation, and Goals Analysis}

Research problems in the form of Statement of Problem or Problem Formulation is the basic of research. It is closely related to the goal of research in which the goals will answer or clarify the problems. To make the research focus, there will be scope and limitation of research. Scope is a broader term than limitation and these terminologies have already been understood by the student researchers in their theses/paper.

Yuliastuti (2005) focused the problem on conscious and unconsciousness of the main character, limited by applied theories, and the goals would answer the problem, that was finding reason why the main character doing unpredictable and destructive actions. Wijaya (2010) stated problem formulation on how racism belief development and its impacts to the main characters, scope mentioned the used movie, and the two brother characters, and the goals indicated answer to the problem formulation that was to find out factors that influence the understanding and practice of racism between the two brothers. Kristiani (2009) stated in her problem formulation on how the main character become a hero but also regarded as the "other" by society. Her scope of research is the main character and the goal was the answer for the problems. Yuliana (2009) mentioned problem formulation on why the sign and meaning can be understood by readers, scope indicated the media (wordless comic) and the readers, and finally the goals stated the answer to the problem formulation. Liaury (2004) stated her statement of problems on how, reason, and appropriate treatment for the destructive behaviour of the main character, scope indicated the main character behaviour, and the goals clarified the problems.

Conclusion for the above analysis indicated that all the student researchers already understand the meaning and function of statement of problems or problem formulation, scope and limitation, as well as goals of researches. It means that "relevance", "clearness", and "logical thinking" have been mastered by students.

\section{Research Methods Analysis}

Research methods for thesis and paper in Binus were located in Chapter 1 because formerly it was a research proposal that have been approved. There are disadvantages of presenting research method in chapter one due to its limitation of 100 to 250 words, Therefore they could only describe the type and sequence of used methods and it would be too limited and unclear. Research methods consist of research paradigm that has been chosen, why this methods are appropriate to this research, the positive as well as negative views, respondent selection and its reason, instrument, such as questionnaires, interview guidelines, other infrastructure, data collection, analysis, and evaluation, as well as conveying the research results into conclusion that is related to the goals or research. In fact, the presentation of research methods in the study is as follows.

Thesis No 1 by Yuliastuti (2005) mentioned the research steps , those were library research as the basic analysis, read the novel, find textbooks and reference books at the library, finding data from internet, and apply the theories. Thesis No 2 by Wijaya (2010) mentioned library research as the basic analysis, the steps of doing the research: seeing and analyzing movies, finding textbooks, articles, thesis, and reference book. Theories were found from the textbooks and primary research analysis, analyzing film scripts evaluated by selected theories and concepts, analyzing information, and drawing conclusions. 
Thesis No 3 by Kristiani (2009) mentioned library research as the basic analysis, then followed by steps she did : watching and matching script to the film, finding and select literatures for theories, how to analyze the media and related theories. Maria told the steps very detail but she did not mention the relationship between the research results and the goals. Thesis No 4 by Yuliana (2009) mentioned library research to consider theories and field research by distributing questionnaires to respondents, reason to consider respondent, time, place, and instruments of research. This was better way to present research method, but she did not mention data collection, analysis, and evaluation in drawing the conclusions. Paper No 5 by Liaury (2004) mentioned library research as the basic research, finding textbooks, and place to find those literatures, such as Binus, Atmajaya, and UI libraries.

Based the five research methods presentations, it can be concluded that students have not comprehended on how to present research methods. They just decide the methods and told their steps to do. The thesis instructor (lecturers) should guide them what is meant by research methods, what is the requirements, and drawing solution. Generally, the students present details of their methods steps. Only on thesis No 4, the author was able to mention research specification, even though she did not mention data management until finding conclusions.

Students generally cannot present a reason or justification of selecting the methods, including what is the strength and weakness of that methods. This also will apply to the respondent and instruments considerations. It seems that students imitated the past researches that will be applied in theirs. In general they only present the research steps, as follows:

The research method that the writer used ... is library research. First, the writer read the novel.... Then, the writer looked for the reference books in ... that related to topic. In completing others information, the writer looked for some data in the internet. And at last, the writer used .... in doing analysis. (thesis No 1)

\section{Quotation Analysis}

In presenting theoretical background in Chapter II, the students should master on how to quote others' works for direct quotation, and the skill of paraphrasing for indirect quotation. After reading the five theses and papers, it seems that sometimes students cannot paraphrase because they do not know how to do this, or they think that if they already paraphrase, they do not need to mention the sources (authors). The presentation of direct quotation in APA style is as follows:

- "Plot is the sequence of incidents ... composed" (Perrine, 1970. P.42)—(Thesis No 1)

- According to Kennedy (2003)," exposition usually in the beginning ....introduced”. - (Thesis No 1)

- $\quad$ Kelley Griffith (2006) has clearly mentioned the differences by defined the character is a person....(p.54) - (Thesis No 2)

- Character can be defined as,” All the mental or moral qualities ...others,”(1995, p.186) - (Thesis No 2)

- $\quad$ Di Yani (2000,p.55) said,” Static or unchanging character, they ....Progress.” - (Paper No 5)

- Point of view is,” The position from which .....” (Stanford, 2003, p. 32) - (Paper No 5)

From those six direct quotations it can be said the students already know how to do a direct quotation. They mentioned authors, year of publications, and related pages. There were two types of direct quotation, the author as the first statement before presenting the content and when the authors were mentioned after the clarification of the content. As of the regulation, the length of content is less than 3 lines or less than 40 words. The quotation is embedded in one paragraph. 
Besides the correctness in doing direct quotation, there are still some mistakes in doing indirect quotation. Indirect quotation was done for the sources length was more than 3 lines or 40 words, so that they have to quote in separate paragraphs. The name of the author or sources must be mentioned. Or, they have to paraphrase in paragraphs. Examples presented by the chosen thesis were as follows.

- $\quad$ In China the eldest man is the head of the family. He has the authority of the family, while the younger and women have less power.

- Elder men held a strongest power within the family, and the young

The young, both women and men, had very little say in decisions that involved them (Riley, 1994, p.2).

- In the journal entitled ....., Tsui ( 1989, p. 737-738) wrote that there are five types of family in China. (Paraphrasing)

(etc.). (Theses No 3)

- Point of View

Point of view is," (original text) ." (Stanford, 2003, p.32)

Kennedy (1979,p.18) said that ,"Narrator is (original text) ... " and he divided

Narrator into six categories:

Narrator as a participant (writing in the first person) - (original text)

1. (term, original text)

2. (term, original text)

Narrator as a non-participant (writing in the third person) - (original text)

1. (term, original text)

2. (term, original text)

3. (term, original text)

4. (term, original text) --(Paper No 5)

From those two examples consisting of a undergraduate theses and a paper, it can be seen that the two students already know how to quote and paraphrase properly, even students who wrote undergraduate theses was able to compare one author's thought with others in the form of literature review. But, the author of paper 5 was still unsure to how to do paraphrasing; she wrote all the original text from the textbook even in the same format, (see her numbering style). One thing that is good is that she still puts the source in the quotation.

For all student researchers, the style of writing quotation and paraphrasing still can be developed by finding literatures that are not similar so that theoretical backgrounds as well as literature review become interesting, because the researchers are able to present argumentative ideas of the authors/experts.

\section{Making Evidences Analysis}

Since the three theses and one paper samples using library research, the analysis was done by applying intrinsic element of literature consisting of exposition (character, setting, motivation, and basic conflict), conflict, climax, and resolution; some theories related to the main character or topic analysis, such as semiotics, Psychoanalysis by Freud, Feminisms, Racism, etc. On the text or film pictures. One thesis used quantitative research. The presentation of evidences is as follows. 


\section{(Thesis No 2)}

There is a statement from Derek when he acts as second leader ... to the young skinheads, as follows:

- "All right, listen up. We .... (evidence, original text, 8 lines, 120 words) ................" (sources)

- $\quad$ The statement from Derek about their country condition makes sense ...... He mentions about the loss (students' statement analysis, 2 paragraphs (6 lines ; 11 lines)

Thesis No 4 presented quantitative methods that were analysis based on collected questionnaires using descriptive analysis as follows.

- Research Methodology covers instruments, data collection, (1 paragraph)

- Instrument (3 paragraphs, including filling questionnaire examples)

- Data Collection (2 paragraphs)

- Population and Sample (1 paragraph)

- Analysis (11 paragraphs, including pictures analysis, table)

Paper No 5 presented her analysis by showing evidences as follows.

Protagonist Character

1. Sheila is a brave child, she never presents her cowardice (student statement)

\section{(1 paragraph evidence, original text )}

2. If she is annoyed by others she will fight (student statement) .................... (1 paragraph evidence, original text from the novel)

3. Good Physical Endurance ( student statement) ..(1 paragraph, clarification: student statement ) ............................. (1 paragraph evidence, original text from the novel)

Based on the three analyses, it can be concluded that students already know how to show evidences as well as analysing data of quantitative research. Balance of students' statement commenting or clarifying original text as evidences is good, except for the beginning analysis done by the research paper. Imelda just gives a short clarification (1 paragraph) for one paragraph evidence. It shows that her critical thinking as D3 student is still limited compared to S1 students. Theses done by S1 students are able to analyse or clarify the evidences better, in which for 1 paragraph evidence he is able to clarify with the length of more than one paragraph. And, student who did quantitative research was able to present her analysis that meet clarity, relevance, and critical thinking aspects.

\section{Plagiarism}

Plagiarism is a presentation of others' words, sentence, and ideas as her/his own. This occurs when a writer clearly uses language, ideas, and primary sources, without mentioning its original sources (name, title, publication year, related pages). As of information literacy concept, one of the requirements is the students' ability to use the information legally and ethically. It means that they cannot do plagiarism practices. In practice, students' thesis and paper presentation related to plagiarism is as follows. 
- $\quad$ Thesis No 1 mentioned the chosen novel, author's bibliography and her published works without mentioning the sources in Chapter 1 (background of study). In Chapter 2 she put the correct quotation on her theories and concept presentation, and she put pages on the quoted original sources in Chapter 3.

- Thesis No 2 is not guilty of plagiarism by mentioning the sources in Chapter 1 (background of study, literature review), Chapter 2 (definition, concept), and in Chapter 3 (evidences).

- Thesis No 3 has successfully avoid plagiarism by mentioning the sources in Chapter 1 (background of study, literature review), Chapter 2 (definition, concept), and in Chapter 3(evidences).

- Thesis No 4 did not mentioned sources in her two paragraphs in the background of study (Chapter 1), good quotation in Chapter 2, and she did not supposed to put the sources in Chapter 3 because she already collected, tabulated, and analysed data in Chapter 3.

- $\quad$ Paper No 5 did not mention source in one paragraph in the background of study. In Chapter 2 she mentioned sources in her definition and concept presentation, but her quotation was quite lengthy and not paraphrased. In Chapter 3 she is good in quotation.

Based on the above analysis, it can be concluded that the five students are aware of avoiding plagiarism in their theses/paper. Thesis No 1 and paper No 5 neglected to put the sources, but for one or two paragraphs in her background of study. This is maybe because the authors think that if they have paraphrased the content, they do not need to put the sources. Therefore, socialization on how to do the right quotation and paraphrasing must be developed so that students are more aware.

\section{Conclusion and Suggestions Analysis}

Conclusions are clear and concise statements that should be in line with problem formulation and goals of the research. The problems encountered by students are their incapability to draw conclusions based on the theories in Chapter 2 and analysis in Chapter 3. Usually, they still repeated their statements in Chapter 3 without making its in line with problem formulation as well as goals. Here are conclusions from the selected theses and paper.

Thesis No 1: Conclusions consists of 6 paragraphs and not really related to one problem formulation having optional question (whether or not) . There are still two paragraphs repetition from the analysis in chapter 2, saying," Sheila is a child who lack of love and care, especially from her Ma and Pa...” and ," All of Sheila's actions and behaviour cannot be understood by many people....". The main ideas of those two paragraphs are related to problems formulation but the supporting ideas are imitating sentences that have mentioned in Chapter 3. The rest 4 paragraphs tend to state Sheila' parents bad behaviours to her than analysing her conscious and unconscious deeds.

Thesis No 2: Conclusions consist of 7 paragraphs and related to one problem formulation having how and why questions related to the topic. The answer in the conclusion presented a comparison between the two main characters experiences in understanding and applying racism belief until they are recovered. Thesis No 3: Conclusions consist of 3 paragraphs and related to 3 problem formulation having "how" questions related to hero and "the other" topics. Each paragraph in the conclusion answers one problem formulation, and it si the ideal one.

Thesis No 4: Conclusions consist of 7 paragraphs and related enough to the 3 questions on understanding, comprehension, and relationship between sign and its meanings. Conclusion presented evaluation of data analysis based on quantitative research that already answer the research problems but still needs skill in conciseness. Paper No 5: Conclusions consists of 5 paragraphs and not related enough to the 3 problems formulation on "how" and "what" questions on Sheila's specific behaviour. There were only 3 paragraphs that answered problem formulation, and the other two paragraphs represent suggestions on how appropriate treatments for Sheila, and the other paragraph presented on 
how parents must behave properly to their children so that they could grew to be good children. These two paragraphs the fact belong to the suggestion, not conclusions.

Based on the above explanation it can be concluded that students are still get difficulties in relating problems formulations and conclusions. They usually more focus on drawing conclusions from the analysis, and consequently not all problems formulations can be answered. To remedy this matter, a good guidance from the mentors are needed to patiently clarify to the students on how to relate problem formulations, goals, and conclusions. Lecturers can select a proper thesis and discuss it in class.

\section{Suggestion Analysis}

Suggestions are optional. It can be a chance of the future research that can be done by the next students. Most of the researches presents conditions or suggestions related to the topic and analysis, such as, parents and teacher proper behaviour for the "special" child (thesis No 1, paper No 5); the chance of applying different theories and comparing media for the next research (thesis No 2), suggestion for using media non-comic (thesis no.4), and no suggestion for thesis No 3 . Therefore, it can be concluded that suggestions written on the above theses and paper are based on the analysis and development of future research. Suggestions present a chance for developing other research based on the available weaknesses, are shown in thesis 2 and thesis 4 . While suggestions which is based on the analysis are presented in thesis no.1 and paper no.5. It had better present suggestion related to the future research than just based on the analysis.

\section{Summary Analysis}

Summary clarifies the research in Bahasa Indonesia describing the research in order nonIndonesia readers understand the background, methods, theories, analysis, and conclusion that have been presented in Chapter 1 up to Chapter 5 of the research. The study indicates that Thesis No 1 , thesis no 2, and thesis no 3 presented background of study and research process in Chapter 1 to Chapter 5. Thesis no 4 presented background of research, quantitative research methods, and research report presentation from Chapter 1 to Chapter 5 . The last paper presented background of study and a slight description of research in Chapter 1 to Chapter 5.

From the above analysis it can be concluded that all the students already understand the content of Summary of thesis/paper in Chapter 1. The weakness of presentation is in their bahasa Indonesia yang baik dan benar application in which most of them are still influenced by English translation, for example the using of the words di mana dan dari which is supposed to be translated from," New York is a place where Daniel was born", where it should have been translated into "New York adalah tempat Daniel dilahirkan.". Also, the phrase "the result of research" is translated into "hasil dari riset", which should have been only "hasil riset".

Student weaknesses among others are not being able to differentiate between "di" as a prefix written separately (di awal, di antara) and "di" as a a verb which should have been written together (dipukul, dibeli). Also with splitting of compound words such as tanggung jawab, bertanggung jawab, andpertanggungjawaban.

\section{Bibliography Analysis}

Writing references or bibliography is based on APA style. It is done for textbooks (author, year of publication, title, (edition), city, publisher); articles (author, (month, year), title of article, title of journal, volume, number, and related page. If the writers use articles from the internet, they have to mention year of upload, time when the writers get the information, and its IRL address. Based on APA style, author is written by last name first and followed by its initials, except for Indonesian 
names where often there is no last name. Title of book/article is written by proceeding capital letter, followed by title case, except for personal name and place.

As for the rules, the students wrote their bibliographies as follows.

Paper No 5 (2004)

Textbook:

Di Yanni, R. (2000). Literature.Reading Fiction,Poetry and Drama. Singapore: McGraw-Hill Companies,Inc.

Internet source:

Hein, S. (2004). Definition and History Emotional Intelligence. Retrieved on March 19,2004, from (http://www.google.com)

Thesis No 1 ( 2005):

Textbook, written :

Di Yanni, R. (2000). Literature_Reading Fiction, Poetry and Drama. Singapore: McGraw -Hill International.

Correction:

Di Yanni, R. (2000). Literature: Reading Fiction, Poetry, and Drama. Singapore: McGraw Hill International.

Internet source:

Stringer, Kathi. Defence Mechanism. Retrieve on March 5,2005 from http://www.toddlertime.com/terms/defence.htm.

Thesis No 3 (2009)

Textbook :

Di Yanni, R. (2001). Literature Reading Fiction, Poetry, and Drama. New York: McGraw-Hill Higher Education.

Internet Source :

Ming Tsui. (1989). Changes in Chinese Urban Family Structure. Journal of Marriage and the Family, 15 (3),737. Retrieved June 23, 2009, from ProQuest Sociology Database. (document ID: 1718078).

Thesis No 2 (2010)

Textbook:

Barry, P. (2009). Beginning Theory: An Introduction to literary and cultural theory. New York : Manchester University Press.

Journal Article :

Lane, C. (2002). Psychoanalysis and colonialism redux: Why Mannoni’s "prospero Complex" still haunt us .Journal of Modern Literature, 25. Retrieved April 20, 2010 from http://proquest.umi.com/pqdweb?did=464582531\&sid=1\&Fmt$\underline{4 \& \text { clientId }=68814 \& \mathrm{RQT}=309 \& \text { Vname}=\mathrm{PQD}}$

The above analysis based on year representation it can be concluded that even though the English Department has clearly described APA style in writing bibliography, the students still wrote in different verses. It means that the students do not why they must follow the rules, especially with the using of capital letter, title case, coma, space, how to write author name, etc. Also, there is a tendency 
that the lecturers who guided them did not check these bibliographical lists; they more focused in the research contents.

The fact, writing bibliographies or references must be checked its information because the next researchers have to find them for doing the next research or other academic writings. Details of bibliography must be traceable, therefore do not give wrong information for scientific writing. Example that can be seen from the analysis is the city and publisher name for Di Yanni's textbooks. Paper No 5 mentioned Singapore: McGraw-Hill Companies, Inc.; whereas thesis No 1 mentioned: Singapore: McGraw -Hill International; thesis No 3 mentioned: New York: McGraw-Hill Higher Education. Those facts must be checked by the students and lecturers by asking them to bring the sources and then check the references together.

\section{Abstract Analysis}

After writing undergraduate theses, the writer should complete it with abstract which is a "miniature" of the research. Abstract functions as a "short description" in which the readers can grasp the research done. The reader then may decide to continue to read the whole thesis or not. Abstract consists of goals, method, analyse, and conclusion of the research (APA, 2007). Hyland (2000:67) mentions rhetorical moves in an abstract; those are introduction, purpose, method, product, and conclusion.

In the study, all of the students abstract consisted of goals of the research, applied methods, analysis, and conclusions in one paragraph consisting of 150-250 words.

\section{Rubric Based Analysis}

Based on Table 2 on research paper rubric, the thesis and paper presentation is shown in Table 3.

Table 3 Presentation of Theses and Paper in the Research

\begin{tabular}{|c|c|c|c|c|c|}
\hline & Thesis No 1 & Thesis No 2 & Thesis No 3 & Thesis No 4 & Paper No 5 \\
\hline $\begin{array}{l}\text { Integration of } \\
\text { knowledge }\end{array}$ & $\begin{array}{l}\text { Proficient, because } \\
\text { she mostly has } \\
\text { applied the } \\
\text { conscious and } \\
\text { unconscious } \\
\text { behaviour on the } \\
\text { main character that } \\
\text { lead to answer the } \\
\text { research's } \\
\text { problem. }\end{array}$ & $\begin{array}{l}\text { Expert, because he } \\
\text { fully understand } \\
\text { and has applied } \\
\text { concepts of the } \\
\text { development of } \\
\text { racism on the two } \\
\text { brothers based on } \\
\text { the correct theory } \\
\text { and concept. The } \\
\text { analysis answers } \\
\text { statement of } \\
\text { problems. }\end{array}$ & $\begin{array}{l}\text { Proficient, } \\
\text { because she, } \\
\text { mostly, has } \\
\text { applied the } \\
\text { heroic and "the } \\
\text { other" concepts } \\
\text { to analyse the } \\
\text { main character } \\
\text { that answer the } \\
\text { research } \\
\text { problems. }\end{array}$ & $\begin{array}{l}\text { Expert, because } \\
\text { she fully } \\
\text { understand and } \\
\text { has applied } \\
\text { concepts of } \\
\text { semiotics to the } \\
\text { wordless comic } \\
\text { analysis. This will } \\
\text { answer the } \\
\text { research } \\
\text { problems. }\end{array}$ & $\begin{array}{l}\text { Apprentice, } \\
\text { because the } \\
\text { author, } \\
\text { understand and } \\
\text { applied some } \\
\text { concepts on the } \\
\text { analysed novel } \\
\text { to answer the } \\
\text { research } \\
\text { problems }\end{array}$ \\
\hline Topic Focus & $\begin{array}{l}\text { Proficient, because } \\
\text { the topic is } \\
\text { appropriately focus } \\
\text { but lacks of } \\
\text { direction, she did } \\
\text { not mention thesis } \\
\text { statement. }\end{array}$ & $\begin{array}{l}\text { Proficient, } \\
\text { The topic is } \\
\text { appropriately } \\
\text { focused but lacks } \\
\text { direction. There is } \\
\text { no thesis statement. }\end{array}$ & $\begin{array}{l}\text { Proficient, there } \\
\text { is no clear thesis } \\
\text { statement as } \\
\text { analysis } \\
\text { guidance. }\end{array}$ & $\begin{array}{l}\text { Proficient, } \\
\text { there is no clear } \\
\text { hypothesis for } \\
\text { analysis guidance. }\end{array}$ & $\begin{array}{l}\text { Apprentice, } \\
\text { because the } \\
\text { topic is broad } \\
\text { and there is no } \\
\text { thesis statement. }\end{array}$ \\
\hline
\end{tabular}


Table 3 Presentation of Theses and Paper in the Research (continued)

\begin{tabular}{|c|c|c|c|c|c|}
\hline & Thesis No 1 & Thesis No 2 & Thesis No 3 & Thesis No 4 & Paper No 5 \\
\hline $\begin{array}{l}\text { Depth of } \\
\text { Discussion }\end{array}$ & $\begin{array}{l}\text { Proficient, } \\
\text { In-depth } \\
\text { discussion \& } \\
\text { elaboration in most } \\
\text { sections of the } \\
\text { paper. }\end{array}$ & $\begin{array}{l}\text { Expert, } \\
\text { In-depth discussion } \\
\text { \& elaboration in all } \\
\text { sections of the } \\
\text { paper. }\end{array}$ & $\begin{array}{l}\text { Proficient, } \\
\text { In-depth } \\
\text { discussion \& } \\
\text { elaboration in } \\
\text { most sections of } \\
\text { the paper. }\end{array}$ & $\begin{array}{l}\text { Expert, In-depth } \\
\text { discussion \& } \\
\text { elaboration in all } \\
\text { sections of the } \\
\text { paper. }\end{array}$ & $\begin{array}{l}\text { Proficient, } \\
\text { In-depth } \\
\text { discussion \& } \\
\text { elaboration in } \\
\text { most sections of } \\
\text { the paper. }\end{array}$ \\
\hline Cohesiveness & $\begin{array}{l}\text { Proficient, } \\
\text { ties most } \\
\text { reference } \\
\text { information from } \\
\text { all sources }\end{array}$ & $\begin{array}{l}\text { Expert, } \\
\text { ties all reference } \\
\text { information from } \\
\text { all sources }\end{array}$ & $\begin{array}{l}\text { Proficient, ties } \\
\text { most reference } \\
\text { information from } \\
\text { all sources }\end{array}$ & $\begin{array}{l}\text { Proficient, } \\
\text { ties most } \\
\text { reference } \\
\text { information from } \\
\text { all sources }\end{array}$ & $\begin{array}{l}\text { Apprentice, } \\
\text { Sometimes ties } \\
\text { together } \\
\text { information } \\
\text { from all sources. }\end{array}$ \\
\hline $\begin{array}{l}\text { Spelling \& } \\
\text { Grammar }\end{array}$ & $\begin{array}{l}\text { Apprentice, } \\
\text { Noticeable spelling } \\
\text { \& grammar } \\
\text { mistakes. }\end{array}$ & $\begin{array}{l}\text { Proficient, minimal } \\
\text { spelling \&/or } \\
\text { grammar mistakes. }\end{array}$ & $\begin{array}{l}\text { Apprentice, } \\
\text { Noticeable } \\
\text { spelling \& } \\
\text { grammar } \\
\text { mistakes. }\end{array}$ & $\begin{array}{l}\text { Proficient, } \\
\text { minimal spelling } \\
\text { \&/or grammar } \\
\text { mistakes. }\end{array}$ & $\begin{array}{l}\text { Apprentice, } \\
\text { Noticeable } \\
\text { spelling \& } \\
\text { grammar } \\
\text { mistakes. }\end{array}$ \\
\hline Sources & $\begin{array}{l}\text { Apprentice, fewer } \\
\text { than } 5 \text { current } \\
\text { sources from } 15 \\
\text { textbooks. }\end{array}$ & $\begin{array}{l}\text { Proficient, there } \\
\text { are } 5 \text { current } \\
\text { sources of } 23 \\
\text { textbooks, } 1 \text { thesis, } \\
2 \text { Peer reviewed } \\
\text { journal article, and } \\
1 \text { reference book. } \\
\text { Websites utilized } \\
\text { are authoritative. }\end{array}$ & $\begin{array}{l}\text { Apprentice, } \\
\text { From } 9 \\
\text { references, she } \\
\text { only got one } \\
\text { journal article by } \\
\text { Ming Tsui and it } \\
\text { was not deeply } \\
\text { analyzed. }\end{array}$ & $\begin{array}{l}\text { Apprentice, } \\
\text { fewer than } 5 \\
\text { current sources of } \\
19 \text { textbooks and } \\
3 \text { reference books } \\
\text { in her References, } \\
\text { there was no } \\
\text { article. }\end{array}$ & $\begin{array}{l}\text { Apprentice, } \\
\text { fewer than } 5 \\
\text { current sources } \\
\text { of } 11 \text { textbooks } \\
\text { and no article. }\end{array}$ \\
\hline Citations & $\begin{array}{l}\text { Proficient, Cites } \\
\text { most data obtained } \\
\text { from other sources. } \\
\text { APA citation style } \\
\text { is used in both text } \\
\text { and bibliography. }\end{array}$ & $\begin{array}{l}\text { Proficient. } \\
\text { Cites most data } \\
\text { obtained from } \\
\text { other sources. APA } \\
\text { citation style is } \\
\text { used in both text } \\
\text { and bibliography. }\end{array}$ & $\begin{array}{l}\text { Proficient. Cites } \\
\text { most data } \\
\text { obtained from } \\
\text { other sources. } \\
\text { APA citation } \\
\text { style is used in } \\
\text { both text and } \\
\text { bibliography. }\end{array}$ & $\begin{array}{l}\text { Proficient. } \\
\text { Cites most data } \\
\text { obtained from } \\
\text { other sources. } \\
\text { APA citation } \\
\text { style is used in } \\
\text { both text and } \\
\text { bibliography. } \\
\text { Does not cite } \\
\text { sources. }\end{array}$ & $\begin{array}{l}\text { Proficient. Cites } \\
\text { most data } \\
\text { obtained from } \\
\text { other sources. } \\
\text { APA citation } \\
\text { style is used in } \\
\text { both text and } \\
\text { bibliography. }\end{array}$ \\
\hline
\end{tabular}

\section{CONCLUSION}

Based on the format analysis on the 4 thesis and 1 paper it can be concluded that: (1) In the Introduction in Chapter 1: Students still find difficulties in writing their background of study. Usually they write problems formulation instead of why are they interested in the topic. They also cannot differentiate between statement of problem and the problem formulation. Research method only mentions the steps of collecting data; (2) Students present theoretical background are only inspired by the former thesis/paper. They cannot analyze what is the advantage and disadvantage of its theory related to the chosen topic. Solutions can be done by giving then skills in information retrieval and making literature review from the primary source; (3) The format of theses and paper should be more socialized to both students and lecturers who guide them so that the quality of theses and papers can be achieved; and (4) Cooperation with library and Language center are needed to improve students' ability in information retrieval and writing skills. 


\section{REFERENCES}

American Psychological Association. (2007). Concise rules of APA style. Washington, DC: American Psychological Association.

Binus University English Department, (2010). Thesis Guidelines, Jakarta: Binus University.

Cooley, L., \& Lewkowicz, J. (2003). Dissertation writing in practice. Turning ideas into text. Hongkong: Hongkong University Press.

Cornell College \& Colorado College (2004), Examples of assessment tools, Downloaded from http://www.coloradocollege.edu/library/acmassign/tools.html

Kristiani, M. H. I. (2009). An Analysis of Woman's Struggle in Upholding the Family Honour in a Walt Disney Movie Mulan, Unpublished undergraduate theses, Binus University

Liaury, I. (2004). An Analysis of Sheila's Character in One Child by Torey Hayden. D3 Program Final Paper.

Hyland, K. (2000). Disciplinary discourse: Social interactions in academic writing, New York: Longman

Wijaya, W. (2010). The Analysis of Racism through Characters Derek Vinyard and Daniel Vinyard in American History $X$ Movie , Unpublished undergraduate theses, Binus University

Yuliana, S. (2009). Semiotic Analysis on Sign Across Non-Verbal Communication in Ferd'nand Wordless Comic Strip, Unpublished undergraduate theses, Binus University

Yuliastuti. (2005). Analysis of the Conscious and Unconscious Mind of Sheila's Behavior in One Child by Torey Hayden, Unpublished undergraduate theses, BINUS University 